\title{
EFEKTIVITAS PROGRAM PSIKOEDUKASI PENGEMBANGAN SELF- ESTEEM UNTUK MENINGKATKAN SELF-ESTEEM REMAJA KELAS 1 DI SMP X
}

\author{
Beta Oktalia $^{1}$, Sri Tiatri ${ }^{2}$, dan Heni Mularsih ${ }^{3}$ \\ ${ }^{1}$ Program Studi Magister Psikologi, Universitas Tarumanagara Jakarta \\ Email: beta_oktalia@yahoo.com \\ ${ }^{2}$ Fakultas Psikologi, Universitas Tarumanagara Jakarta \\ Email: sri.tiatri@untar.ac.id \\ ${ }^{3}$ Fakultas Psikologi, Universitas Tarumanagara Jakarta \\ Email: henim@mku.untar.ac.id
}

\begin{abstract}
The transition period of adolescents from elementary school to junior high school is a stage of development full of changes and challenges. During this transition period, adolescents become vulnerable and the level of self-esteem tends to decrease. The transition period to junior high school is the right period of development for primary low self-esteem preventive interventions, and to improve self-esteem of adolescents with low self-esteem. Self-esteem is an individual's positive or negative attitude in assessing and accepting him/herself holisitically which describes an individual's belief in his/her own sense of worth. The purpose of this study is to determine the effectiveness of the psychoeducation program for the development of self-esteem to improve self-esteem of first grade adolescent students in junior high school X. The participants of this research are eight first grade junior high school students ranging from 12-13 years old at X school Jakarta who had self-esteem issues. The method used is quantitative research that is quasi-experimental with one group pre-post-test research design. The result of the participants' pretest and post-test paired sample T-Test shows $(Z=0.17, p>0.05)$. The result shows that despite an increase in the Self-Esteem score after intervention, this increase is not statistically significant. Thus, the psychoeducation program for the development of self-esteem carried out in this study is ineffective in improving self-esteem of first-grade adolescent students in X junior high school.
\end{abstract}

Keywords: self-esteem, psychoeducation, adolescents, junior high school, intervention.

\begin{abstract}
ABSTRAK
Masa transisi remaja dari sekolah dasar ke sekolah menengah pertama adalah tahap perkembangan yang penuh dengan perubahan dan tantangan. Selama masa transisi ini, remaja menjadi rentan dan tingkat self-esteem cenderung menurun. Masa transisi ke sekolah menengah pertama merupakan periode perkembangan yang tepat untuk intervensi pencegahan primer atas penurunan self-esteem, dan untuk meningkatkan self-esteem remaja yang memiliki low self-esteem. Self-esteem merupakan sikap positif atau negatif individu dalam menilai dan menerima dirinya secara holisitik yang menggambarkan keyakinan individu akan rasa berharga diri sendiri. Tujuan penelitian ini adalah untuk mengetahui efektivitas program psikoedukasi pengembangan self-esteem untuk meningkatkan selfesteem remaja kelas 1 SMP di SMP X. Partisipan penelitian adalah 8 orang siswa kelas 1 SMP berusia 12-13 tahun di sekolah X Jakarta yang memiliki masalah self-esteem. Metode yang digunakan adalah penelitian kuantitatif yang bersifat eksperimen-kuasi dengan desain penelitian one group pre test-post test. Hasil pre-test dan post-test partisipan dengan paired sample T-Test menunjukkan $(Z=0.17, p>0.05)$. Hasil penelitian menunjukkan bahwa meskipun terjadi peningkatan skor Self-Esteem sesudah intervensi, kenaikan ini secara statistik tidak signifikan. Dengan demikian, program psikoedukasi pengembangan self-esteem yang dilaksanakan dalam penelitian ini tidak efektif untuk meningkatkan self-esteem remaja kelas 1 SMP di SMP X.
\end{abstract}

Kata kunci: self-esteem, psikoedukasi, remaja, Sekolah Menengah Pertama, intervensi.

\section{PENDAHULUAN \\ Latar Belakang}

Self-esteem bukan merupakan sesuatu yang bersifat menetap tetapi dapat berkembang maupun menurun selama berlangsungnya proses kehidupan individu. Rosenberg (1965) mendefinisikan self-esteem sebagai sikap positif atau negatif individu terhadap dirinya. Menurut Rosenberg 
(1965), self-esteem adalah konstruksi unidimensional yang mencerminkan sikap positif atau negatif terhadap diri sendiri, dan dalam pengertian ini melampaui evaluasi area fungsi tertentu. Mruk (2006) mengatakan bahwa dalam proses perkembangan self-esteem terdapat berbagai hal yang penting, seperti: dukungan, rasa hormat dan kehangatan. Di sisi lain, Mruk (2006) menemukan bahwa terdapat tujuh faktor antara orang tua dengan anak yang dapat memengaruhi self-esteem individu, yaitu: (a) faktor biologis, (b) dukungan atau keterlibatan orang tua, (c) kehangatan dari orang tua (penerimaan), (d) harapan orang tua dan konsistensi, (e) pola asuh orang tua, (f) urutan kelahiran, dan (g) modelling.

Pada masa anak-anak, self-esteem cenderung stabil di mana self-esteem mulai mengalami sedikit penurunan ketika individu memasuki usia remaja dalam proses kehidupannya (Lian \& Yusooff, 2009). Tingkat self-esteem pada anak-anak cenderung tinggi karena self-view mereka masih didasarkan pada keterbatasan dalam menerima kenyataan, di mana hal ini memberikan dampak positif pada self-esteem anak (Robin \& Trzesniewski, 2005). Penurunan besar self-esteem selama masa remaja dapat dikaitkan dengan perubahan signifikan yang terjadi selama masa transisi dari masa kanak-kanak hingga masa remaja (Bos, Muris, Mulkens \& Schaalma, 2006). Perubahan pubertas pada anak perempuan terkait dengan gambaran tubuh dan self-esteem yang kurang positif (Brinthaupt \& Lipka, 2002). Selain itu, mereka juga memperoleh kemampuan berpikir formatif (Bos, et al., 2006), sehingga hal ini juga memengaruhi penilaian mereka terhadap diri sendiri dan tingkat self-esteem yang dimiliki. Di sisi lain, pada masa remaja, persahabatan dan hubungan romantis atau seksual menjadi semakin penting (Bos, et al., 2006). Oleh karena itu, remaja menjadi rentan terhadap perasaan ketidakmampuan sosial (Bos, et al., 2006), di mana hal ini juga memengaruhi penilaiannya terhadap self-esteem diri sendiri.

Pada masa remaja awal, mereka juga mengalami transisi dari sekolah dasar ke sekolah menengah pertama (Bos, et al., 2006). Schunk, Zimmerman, dan Barry (2012) menemukan bahwa proses transisi dari sekolah dasar menuju sekolah menengah pertama adalah tantangan besar bagi kebanyakan siswa di mana tugas di sekolah yang diterima menjadi lebih sulit, pemberian ranking menjadi lebih ketat, serta lingkungan menjadi lebih mandiri. Saat seorang siswa memasuki sekolah menengah pertama, ia akan mengalami perubahan kondisi, yaitu perhatian guru akan kemajuan individu mulai berkurang, referensi sosial lebih luas, membangun hubungan dengan teman-teman yang baru, adanya perubahan standar evaluasi, yang mendorong individu mampu menilai kembali kemampuan akademik mereka (Schunk \& Pajares, 2002). Akibatnya, selfesteem remaja mulai menurun pada masa transisi ini.

Masa remaja adalah masa yang penuh dengan perubahan, tantangan dan potensi (Brinthaupt \& Lipka, 2002). Pada umumnya, setiap siswa akan mengalami masa transisi yang penuh dengan berbagai perubahan dan tantangan ketika ia baru mulai memasuki sekolah menengah pertama. Perubahan merupakan sebuah kondisi yang dapat menganggu kehidupan seseorang (Chemers \& Garcia, 2001), salah satunya adalah tingkat self-esteem. Secara khusus, nilai pelajaran siswa cenderung menurun pada saat mereka memasuki kelas 1 SMP.

Dalam realitas, ada sebagian siswa yang mengalami masalah di masa transisi ini dan mengalami penurunan self-esteem, namun di sisi lain sebagian siswa mampu menghadapi berbagai tantangan di masa transisi dan memiliki self-esteem yang tinggi. Fakta memperlihatkan bahwa yang menjadi hal yang terpenting bukan masalahnya, tetapi bagaimana cara individu menangani masalah tersebut (Satir, Banmen, Gerber \& Maria, 2006). Masa transisi seorang siswa bukanlah masalah utamanya, tetapi bagaimana cara siswa menghadapi tantangan tersebut yang menjadi hal terpenting. Apa yang individu pilih untuk dilakukan dan cara mereka melakukannya sebagian besar bergantung pada self-esteem (Guindon, 2010). 
Low self-esteem telah terbukti berkaitan dengan beberapa fenomena negatif, seperti: kehamilan remaja yang lebih tinggi, penyalahgunaan obat-obatan dan alkohol, kekerasan, depresi, kecemasan sosial dan bunuh diri (Guindon, 2010). Hadirnya low self-esteem cenderung menimbulkan berbagai halangan dalam mencapai kesuksesan kinerja (Franken, 2002). Sedangkan, adanya high self-esteem berkaitan dengan hal-hal yang positif. Individu dengan high self-esteem mampu bertahan dalam menghadapi berbagai kesengsaraan karena mereka yakin bahwa mereka mampu tetap bangkit kembali setelah mengalami kegagalan (Franken, 2002).

Bos, Muris, Mulkens, dan Schaalma (2006) mengatakan bahwa selama masa transisi dari sekolah dasar ke sekolah menengah pertama, individu menjadi rentan dan tingkat self-esteem cenderung menurun drastis. Masa ini dinilai sebagai periode perkembangan yang tepat untuk intervensi pencegahan primer terhadap penurunan self-esteem, dan untuk meningkatkan self-esteem remaja yang memiliki low self-esteem. Mengingat dampak negatif yang ditimbulkan oleh rendahnya self-esteem bagi remaja, intervensi peningkatan self-esteem sangat dibutuhkan sehingga remaja dapat memiliki tingkat self-esteem yang tinggi dalam menghadapi masa yang penuh tantangan dan perubahan serta dapat mengembangkan potensinya secara maksimal. Intervensi self-esteem perlu memperhatikan bagaimana persepsi individu yang bersangkutan mengenai penyebab rendahnya self-esteem mereka (Bos, et al., 2006). Salah satu strateginya adalah dengan mengubah sudut pandang individu secara kognitif mengenai atribusi, pencapaian secara global, serta atribusi internal untuk kesuksesan (Bos, et al., 2006). Untuk mengubah sudut pandang individu secara kognitif diperlukannya intervensi dengan pendekatan perilaku kognitif. Bentuk intervensi dengan pendekatan perilaku kognitif dapat dilakukan melalui kegiatan psikoedukasi.

Psikoedukasi didefinisikan sebagai pendidikan kepada masyarakat luas mengenai berbagai konsep atau keterampilan psikologis yang berguna untuk menghadapi aneka masalah kehidupan sehari-hari melalui berbagai jenis media massa (Supriyatiknya, 2008). Psikoedukasi merupakan salah satu praktek yang terbukti paling efektif yang telah digunakan di dalam percobaan klinis dan setting komunitas (Lukens \& McFarlane, 2004). Keefektifan intervensi psikoedukatif ini disebabkan oleh adanya fleksibilitas model, yang mencakup informasi dan alat khusus untuk mengelola keadaan yang terkait, sehingga psikoedukasi memiliki potensi luas untuk berbagai bentuk gangguan dan beragam tantangan hidup (Lukens \& McFarlane, 2004). Upaya peningkatan self-esteem melalui intervensi psikoedukasi pernah dilakukan oleh beberapa peneliti. Pada penelitian berjudul "The Impacts of Somatic Psychoeducation on Self-Esteem" yang melibatkan 17 partisipan, 13 wanita dan empat laki-laki dengan usia mean 46. Ditemukan hasil penelitian yang menunjukkan adanya peningkatan self-esteem yang kuat pada populasi yang pada awalnya menunjukkan tingkat self-esteem rendah sampai yang sangat rendah setelah menjalani intervensi psikoedukasi (Helene, Bouchet, Bois \& Lieutaud, 2017). Selain itu, pada penelitian berjudul "Effect of Psychoeducation on Self-Esteem and Self-Efficacy Among College Students" yang dilakukan terhadap 105 mahasiswa di Saint Louis University, Baguio City, Filipina, ditemukan hasil penelitian yang menunjukkan bahwa hasil pada skor post-test dari kedua kelompok perlakuan secara signifikan lebih tinggi dibandingkan kelompok kontrol setelah delapan sesi psikoedukasi (Ablog \& Calaustro Jr, 2016). Hasil penelitian ini memperlihatkan bahwa intervensi psikoedukasi terbukti efektif dalam meningkatkan self-esteem dan self-efficacy mahasiswa (Ablog \& Calaustro Jr, 2016).

\section{Rumusan Masalah}

Rumusan masalah dalam penelitian ini yaitu: Apakah program psikoedukasi pengembangan selfesteem efektif untuk meningkatkan self-esteem remaja kelas 1 di SMP X? 
Untuk menjawab pertanyaan penelitian, berikut kerangka berpikir dalam penelitian ini:

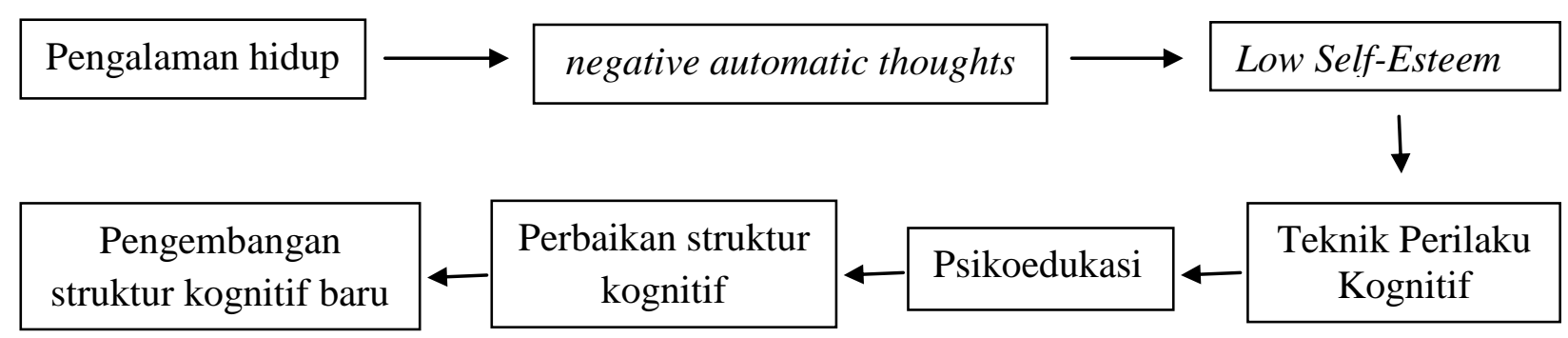

Gambar 1. Kerangka berpikir

\section{METODE PENELITIAN}

\section{Partisipan}

Penelitian ini menggunakan metode purposive sampling. Karakteristik yang ditetapkan dalam menentukan batasan subjek penelitian, yaitu: (a) siswa/siswi berusia 12-13 tahun; (b) kelas 1 SMP; (c) siswa/siswi yang memperlihatkan beberapa hal yang mengarah pada masalah selfesteem (mengalami masalah self-esteem). Berdasarkan karakteristik yang telah ditentukan, penelitian ini melibatkan siswa kelas 1 di SMP X Jakarta. Partisipan berusia 12-13 tahun berjumlah delapan siswa. Partisipan terdiri dari lima kelas regular yang dipilih berdasarkan hasil observasi dari guru bimbingan konseling SMP X.

\section{Alat ukur yang digunakan}

Dalam penelitian ini, peneliti menggunakan alat ukur yang diadaptasi dari Rosenberg SelfEsteem Scale untuk mengukur self-esteem partisipan penelitian. Rosenberg Self-Esteem Scale (RSES) diperkenalkan pada tahun 1965 dalam penelitian Rosenberg pada remaja di negara bagian New York (Hatcher \& Hall, 2009). Reliabilitas untuk alat ukur ini berada di coeffisient alphas .72 hingga .88 (Gray-Little, Williams, \& Hancock, 1997). Silber dan Tippet (1965) melaporkan reliabilitas test-retest selama dua minggu untuk alat ukur RSES sebesar .88 pada sampel mahasiswa (Hatcher \& Hall, 2009). RSES versi bahasa Indonesia terdiri dari lima item pernyataan negatif dan lima penyataan positif dengan menggunakan skala likert. Contoh item pernyataan positif, seperti: secara keseluruhan, saya puas dengan diri saya sendiri. Sedangkan contoh item pernyataan negatif, seperti: saya merasa tidak berguna. RSES versi bahasa Indonesia menunjukkan reliabilitas yang dapat diterima. Poin maksimum untuk RSES adalah 40 poin, sedangkan poin minimum adalah sepuluh poin. Skor yang lebih tinggi menunjukkan tingkat selfesteem yang lebih tinggi.

\section{Prosedur penelitian}

Prosedur penelitian ini dibagi menjadi tiga tahap, yaitu: tahap persiapan, tahap pelaksanaan, dan tahap penutup. Pada tahap persiapan, peneliti menentukan partisipan penelitian, modul intervensi, mempersiapkan alat ukur penelitian berupa pre-test dan post-test serta mempersiapkan berbagai perlengkapan penelitian lainnya. Pada tahap pelaksanaan, peneliti menyerahkan pre-test kepada guru pengawas untuk diberikan kepada seluruh partisipan sebelum penyuluhan disampaikan. Setelah pre-test diisi oleh seluruh partisipan, peneliti akan memberikan intervensi psikologi berupa penyuluhan kepada partisipan penelitian selama tiga kali pertemuan, di mana setiap pertemuan terdiri dari dua modul penyuluhan. Setiap pertemuan berdurasi 120 
menit dan didampingi oleh guru bimbingan konseling kelas 1 di SMP X yang berperan sebagai observer. Peneliti menggunakan modul versi bahasa Indonesia yang diadaptasi dari Wellbeing service di Glasgow (Wellbeing Service, 2015). Pada pertemuan terakhir, seluruh partisipan mengisi post-test. Setelah pelaksanaan intervensi psikologi, peneliti masuk ke dalam tahap penutup. Pada tahap ini, peneliti melakukan diskusi dan evaluasi dengan pihak sekolah mengenai intervensi yang telah dilaksanakan selama tiga kali pertemuan. Setelah evaluasi dilaksanakan, maka peneliti membuat laporan penelitian.

\section{HASIL PENELITIAN DAN DISKUSI}

\section{Hasil Penelitian}

Hasil penelitian menunjukkan bahwa intervensi psikoedukasi yang diberikan kepada partisipan tidak menimbulkan perubahan yang signifikan. Hasil penelitian dari intervensi psikoedukasi terhadap partisipan penelitian tercantum dalam Tabel 1. Secara keseluruhan, pengolahan data menggunakan paired samples T-Test memperlihatkan total skor mean partisipan meningkat setelah diberikan intervensi psikoedukasi dari total skor mean 2.48 dengan Cronbach alpha .88 pada pre-test menjadi total skor mean 2.58 dengan Cronbach alpha .8 pada post-test. Meskipun ada perbedaan total skor mean post-test kelompok setelah diberikan intervensi psikoedukasi, namun berdasarkan yang tercantum pada Tabel 1 menunjukkan bahwa perubahan tidak signifikan. Tabel 1 menunjukkan bahwa intervensi psikoedukasi self-esteem yang diberikan kepada delapan partisipan tidak signifikan $(\mathrm{Z}=0.17, \mathrm{p}>0.05)$. Analisis data dalam penelitian ini diolah dengan menggunakan program SPSS Statistics 23. Untuk mengetahui normalitas data yang diperoleh, maka peneliti melakukan uji normalitas dengan formula One-Sample Kolmogorov-Smirnov Test. Hasil uji normalitas memperlihatkan bahwa data yang diperoleh dinyatakan normal $(\mathrm{Z}=0,20, \mathrm{p}>0,005$ pada pre-test dan $\mathrm{Z}=0,75, \mathrm{p}>0,005$ pada post-test $)$.

Tabel 1. Hasil Pre-Test dan Post-Test Partisipan Dengan Paired Sample T-Test

\begin{tabular}{llcccc}
\hline & Mean & N & Std. Deviation & Std. Error Mean \\
\hline \multirow{2}{*}{ Pair 1 } & Pre-test & 24.75 & 8 & .49 & .17 \\
& Post-test & 25.75 & 8 & .40 & .14 \\
\hline
\end{tabular}

\begin{tabular}{llcccc}
\hline & & N & Correlation & Sig. \\
\hline Pair 1 & Pre-test \& Post test & 8 & .94 & .001 \\
\hline
\end{tabular}

\begin{tabular}{|c|c|c|c|c|c|c|c|c|}
\hline & & & \multicolumn{3}{|c|}{$\begin{array}{l}95 \% \text { Confidence } \\
\text { Interval of the } \\
\text { Difference }\end{array}$} & $\mathrm{t}$ & $\mathrm{df}$ & \multirow[t]{2}{*}{$\begin{array}{l}\text { Sig. (2- } \\
\text { tailed) }\end{array}$} \\
\hline & Mean & Std. Deviation & $\begin{array}{l}\text { Std. Error } \\
\text { Mean }\end{array}$ & Lower & Upper & & & \\
\hline $\begin{array}{l}\text { Pair } 1 \text { Pre-test - } \\
\text { Post-test }\end{array}$ & -.10 & .19 & .07 & -.25 & 0.54 & -1.5 & 7 & .17 \\
\hline
\end{tabular}

Berdasarkan hasil yang tercantum pada grafik 1, digambarkan bahwa empat dari delapan partisipan mengalami peningkatan self-esteem yang ditunjukkan melalui peningkatan skor selfesteem setelah diberikan intervensi psikoedukasi. Tiga dari delapan partisipan memiliki skor self- 
esteem yang sama dan satu dari delapan partisipan mengalami penurunan skor self-esteem setelah diberikan intervensi psikoedukasi.

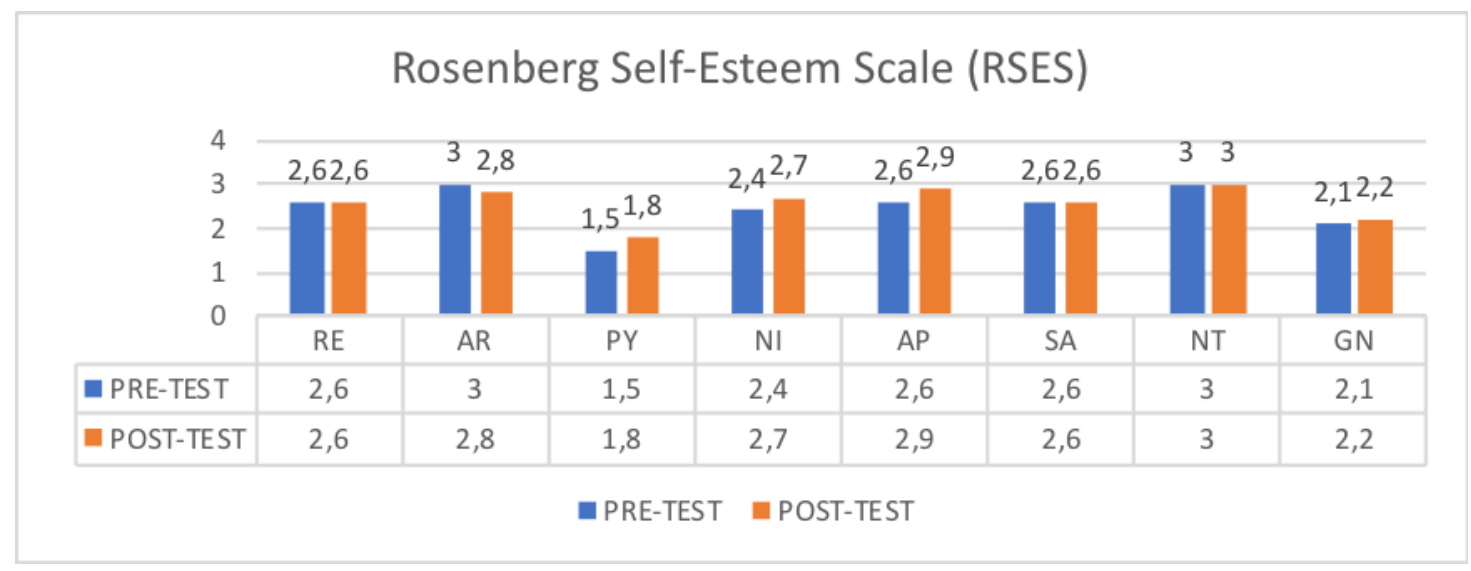

Grafik 1. Skor pre-test dan post-test partisipan dengan menggunakan RSES

Di sisi lain, meskipun tabel 1 menunjukkan perubahan hasil yang tidak signifikan, tetapi setelah diberikan intervensi psikoedukasi, partisipan mengalami perubahan dalam menilai dirinya yang ditunjukkan melalui deskripsi diri yang lebih positif setelah diberikan intervensi psikoedukasi. Meskipun tiga dari delapan partisipan menunjukkan skor yang sama dan satu dari delapan partisipan mengalami penurunan skor pada post-test RSES, mereka menunjukkan adanya perubahan pada diri mereka dalam menilai diri sendiri setelah diberikan intervensi psikoedukasi. Pada hasil pengukuran menggunakan alat ukur kuantitatif dan kualitatif (deskriptif) terlihat ada perbedaan hasil post-test pada partisipan AR. Dalam post-test dengan alat ukur kuantitatif terlihat bahwa setelah mengikuti intervensi psikoedukasi self-esteem, tingkat self-esteem AR menurun, tetapi pada post-test deskriptif terlihat bahwa penilaian AR terhadap dirinya menjadi semakin positif.

Pada intervensi pertemuan terakhir, partisipan juga memberikan umpan balik terhadap intervensi psikoedukasi yang diberikan. Seluruh partisipan menyampaikan umpan balik secara tertulis bahwa melalui intervensi psikoedukasi selama tiga kali pertemuan yang terdiri dari enam modul, mereka mendapat berbagai hal positif yang terkait dengan self-esteem. Partisipan menyatakan bahwa intervensi psikoedukasi yang diberikan membantu mereka untuk mengubah persepsi negatif terhadap diri sendiri. Perubahan ini digambarkan melalui penilaian diri sebelum dan sesudah diberikan intervensi, sebagai contoh: sebelum diberikan intervensi psikoedukasi, partisipan mendeskripsikan dirinya sebagai berikut "Saya adalah orang yang suka pamer", "Saya merasa diri saya kurus", namun setelah diberikan intervensi psikoedukasi, deskripsi partisipan terhadap dirinya sendiri berubah menjadi "Saya adalah orang yang pintar", "Saya merasa diri saya menyenangkan".

\section{Diskusi}

Hasil penelitian menunjukkan bahwa tingkat self-esteem partisipan mengalami sedikit peningkatan setelah diberikan intervensi psikoedukasi, tetapi perubahan tidak signifikan. Hasil penelitian tidak sejalan dengan pendapat Ablog dan Calaustro Jr (2016) yang menyatakan bahwa intervensi psikoedukasi dapat meningkatkan self-esteem individu melalui perubahan keyakinan irasional pribadi tentang diri mereka menjadi keyakinan positif. Selain itu, penelitian ini juga bertolak belakang dengan temuan Lukens dan McFarlane (2004) yang menegaskan bahwa intervensi psikoedukasi merupakan salah satu praktek yang terbukti paling efektif yang telah 
digunakan di dalam percobaan klinis dan setting komunitas. Hasil penelitian juga berbeda dengan hasil penelitian pada penelitian berjudul "Effect of Psychoeducation on Self-Esteem and Self-Efficacy Among College Students" yang dilakukan terhadap 105 mahasiswa di Saint Louis University, Baguio City, Filipina (Ablog \& Calaustro Jr, 2016). Hasil penelitian memperlihatkan bahwa intervensi psikoedukasi terbukti efektif dalam meningkatkan self-esteem dan self-efficacy mahasiswa (Ablog \& Calaustro Jr, 2016). Perbedaan hasil ini dapat disebabkan oleh berbagai hal, seperti: jumlah materi dalam modul dan modul yang digunakan. Pada penelitian ini, materi dalam modul terdiri dari delapan bagian yang dilaksanakan dalam waktu sekitar satu bulan. Selain itu, modul dibuat sendiri dan disesuaikan dengan kebutuhan partisipan. Modul ini juga sudah melalui uji validitas rupa dan validitas konten yang dilakukan oleh para ahli kesehatan mental dan keperawatan kejiwaan. Dalam penelitian yang dilakukan di SMP X, peneliti menggunakan modul yang diadaptasi dari Wellbeing service di Glasgow yang terdiri dari enam bagian dan dilaksanakan dalam waktu sekitar 1 bulan. Spencer, Dupree, dan Hartmann (1997) menyatakan bahwa persepsi pengalaman seseorang dalam konteks budaya yang berbeda mempengaruhi bagaimana seseorang mempersepsikan dirinya. Karena itu, modul yang telah disesuaikan dengan kebutuhan dan budaya partisipan dapat memengaruhi tingkat keberhasil intervensi psikoedukasi self-esteem yang diberikan.

Kajian terhadap hasil penelitian ini memperlihatkan bahwa keberhasilan/ketidakberhasilan intervensi psikoedukasi self-esteem yang dilaksanakan dipengaruhi oleh berbagai faktor, baik faktor internal maupun faktor eksternal. Standar dan nilai pribadi individu terbentuk dari berbagai pengalaman hidupnya, termasuk: lingkungan sosial, afektif, maupun budaya. Hal ini menggambarkan bahwa proses kognitif individu dalam menilai dirinya berkaitan dengan psikososial, afektif, dan budaya individu yang bersangkutan. Secara umum, semakin mendukungnya faktor keluarga, peran orangtua, dukungan lingkungan sosial, hubungan interpersonal, keterlibatan para guru, kondisi fisik, waktu dan tempat pelaksanaan intervensi serta modul intervensi akan memperbesar tingkat keberhasilan intervensi psikoedukasi selfesteem yang diberikan kepada partisipan. Karena jenis penelitian yang digunakan adalah kuasi eksperimen sehingga tidak seluruh aspek dapat dikontrol oleh peneliti, maka terdapat beberapa aspek yang menjadi keterbatasan penelitian, di antaranya: kurangnya kontrol terhadap berbagai faktor lainnya, seperti: keterlibatan pihak lain, hubungan dengan orangtua (informasi yang diperoleh berdasarkan hasil wawancara dengan guru bimbimgan konseling dan partisipan), lingkungan sosial, kesehatan fisik, waktu dan tempat pelaksanaan intervensi. Keterbatasan kontrol terhadap berbagai faktor ini memungkinkan adanya pengaruh terhadap hasil intervensi psikoedukasi yang tidak signifikan.

Keterbatasan penelitian dalam pelaksanaan intervensi sebanyak enam modul yang hanya melibatkan peneliti, partisipan yang bersangkutan dan guru bimbingan konseling. Keterbatasan penelitian yang hanya melibatkan peneliti, partisipan yang bersangkutan dan guru bimbingan konseling, tanpa melibatkan peranan orangtua dan lingkungan sosial diduga menjadi faktor yang memengaruhi hasil intervensi sehingga tidak berpengaruh signifikan. Keterbatasan ini berkaitan dengan kebijakan sekolah dan waktu yang terbatas yang tidak memungkinkan untuk melibatkan orangtua dan lingkungan sosial. Selain itu, pembentukan self-esteem pada anak-anak dipengaruhi oleh peran penting hubungan antara orang tua dengan anak (Lian \& Yusooff, 2009). Berdasarkan data yang diperoleh di lapangan, partisipan memiliki latar belakang pola asuh dan rutinitas keluarga yang berbeda-beda, di mana beberapa partisipan hanya memiliki waktu yang minim dalam berkomunikasi dengan orangtua serta memiliki hubungan yang kurang hangat. Berbagai faktor dari keluarga dapat memengaruhi tingkat self-esteem partisipan dalam pelaksanaan intervensi psikoedukasi, sehingga meskipun intervensi psikoedukasi self-esteem yang 
dilaksanakan memberikan kontribusi positif bagi partisipan, namun faktor keluarga juga berkontribusi penting dalam peningkatan self-esteem partisipan.

Orth, Robin dan Trzesniewski (2010) mengatakan bahwa penelitian sebelumnya menunjukkan kesehatan fisik berpengaruh terhadap perkembangan self-esteem seseorang. Dalam pelaksanaan intervensi psikoedukasi self-esteem di lapangan, beberapa partisipan terlihat mengalami kondisi fisik yang kurang mendukung sehingga beberapa partisipan kurang konsentrasi. Terdapat partisipan yang selama ini mengalami masalah dengan kondisi fisiknya yang mana ia mengalami kelebihan berat badan dan selalu mengantuk sepanjang waktu saat berada di sekolah. Dalam mengikuti intervensi psikoedukasi self-esteem, partisipan mengatakan bahwa ia sangat mengantuk, ingin makan dan merasa kepanasan. Dalam penelitian ini ditemukan bahwa faktor biologis dan keadaan fisik seperti ini memengaruhi konsentrasi partisipan dalam mengikuti intervensi yang diberikan sehingga setiap materi yang diberikan kurang dapat diterima dengan maksimal.

Selanjutnya, dalam pelaksanaan intervensi ini, waktu dan tempat pelaksanaan intervensi disesuaikan dengan kebijakan dan ketersediaan ruangan pihak sekolah. Keterbatasan ruang intervensi yang kurang ideal, seperti: pada pertemuan pertama, ruangan kaca memungkinkan partisipan melihat siswa lain lalu-lalang melintasi ruang intervensi. Selain itu, waktu pelaksanaan intervensi ketika jam pulang sekolah maupun jam istirahat dapat memengaruhi konsentrasi partisipan dalam menerima setiap materi yang diberikan dalam intervensi psikoedukasi selfesteem. Di sisi lain, materi dalam modul yang digunakan menyentuh aspek kognitif namun kurang menyentuh aspek afektif secara langsung. Kurangnya materi yang menyentuh aspek afektif secara langsung dapat mempengaruhi peningkatan self-esteem partisipan dalam pelaksanaan intervensi psikoedukasi self-esteem.

\section{KESIMPULAN DAN SARAN}

Melalui penelitian ini dapat disimpulkan bahwa intervensi psikoedukasi pengembangan selfesteem yang diterapkan dalam penelitian ini tidak efektif untuk meningkatkan self-esteem remaja kelas 1 di SMP X. Penelitian memperlihatkan bahwa meskipun mean skor partisipan meningkatkan setelah diberikan intervensi psikoedukasi, tetapi peningkatan tidak signifikan. Namun demikian, secara umum hasil evaluasi memperlihatkan bahwa partisipan dan pihak sekolah mendapatkan berbagai hal positif dari intervensi psikoedukasi yang diberikan. Melalui intervensi psikoedukasi self-esteem yang diberikan, partisipan belajar untuk lebih menghargai dirinya dan bersikap positif terhadap diri sendiri. Pihak sekolah juga merasakan bahwa materi yang disampaikan sesuai dengan kebutuhan partisipan dan berharap diadakannya program lainnya di kemudian hari.

Berdasarkan hasil penelitian, dapat dikemukakan beberapa saran yang terdiri dari saran teoritis dan saran praktis. Saran teoretis, bagi penelitian selanjutnya yang akan melakukan penelitian mengenai efektivitas program psikoedukasi pengembangan self-esteem untuk meningkatkan selfesteem remaja kelas 1 di SMP X, disarankan untuk melakukan follow up setelah dilakukannya post-test, sehingga efek intervensi psikoedukasi self-esteem yang diberikan dapat dikaji lebih mendalam dan dapat dilihat persistensinya. Di sisi lain, pada hasil pengukuran menggunakan alat ukur kuantitatif dan kualitatif (deskriptif) terlihat ada perbedaan hasil post-test pada partisipan AR. Disarankan dalam pengukuran self-esteem juga sebaiknya menggunakan metode lain (seperti: wawancara, konseling, atau observasi) selain self-report untuk meminimalkan terjadinya bias pada hasil pengukuran serta untuk memastikan pengukuran self-esteem yang lebih objektif dan terpercaya. 
Dalam pelaksanaan observasi untuk menentukan partisipan penelitian, disarankan sebaiknya menggunakan lembar observasi yang memiliki standar pengukuran yang baku, seperti: checklist observasi. Hal ini bertujuan agar hasil observasi dapat mengukur dengan tepat berbagai aspek yang sesuai dengan kebutuhan serta hasil yang diperoleh dapat lebih objektif dan terpercaya. Dalam penelitian selanjutnya juga disarankan sebaiknya peneliti melakukan pengukuran dan mendapat umpan balik dari seluruh partisipan pada setiap modul yang diberikan. Hal ini bertujuan agar hasil yang didapatkan pada setiap modul oleh partisipan dapat dilihat secara lebih jelas dan mendalam. Selain itu, umpan balik yang didapat dari setiap modul juga dapat berguna untuk meningkatkan pelaksanaan intervensi psikoedukasi pada modul selanjutnya. Pada penelitian selanjutnya, checklist hasil observasi guru pada tahap pelaksanaan intervensi disarankan agar tidak hanya dibuat secara keseluruhan, tetapi juga dibuat per partisipan penelitian. Tujuannya agar hasil observasi pelaksanaan intervensi psikoedukasi self-esteem dapat dilihat secara lebih mendalam pada setiap partisipan.

Selain itu, materi modul self-esteem yang akan digunakan sebaiknya juga lebih mengarah dan menyentuh aspek afektif partisipan. Hal ini karena self-esteem sangat berkaitan erat dengan afektif individu sehingga ketika peneliti ingin meningkatkan self-esteem individu, modul yang digunakan perlu lebih menyentuh aspek afektif. Dalam penelitian selanjutnya juga disarankan agar modul yang akan digunakan sebaiknya dibuat sendiri dan disesuaikan dengan konteks budaya partisipan. Hal ini karena para ahli menyatakan bahwa self-esteem individu terkait degan konteks budaya. Materi yang disampaikan juga sebaiknya lebih diperbanyak dengan berbagai contoh nyata sehingga memungkinkan partisipan lebih mudah untuk memahami materi yang disampaikan dan menerapkannya dalam kehidupan sehari-hari. Dalam pelaksanaan intervensi psikoedukasi self-esteem sebaiknya lebih dilengkapi dengan aktivitas yang mendorong partisipan untuk berinteraksi antara satu dengan lainnya. Karena interaksi positif dan dukungan dari teman merupakan sesuatu yang penting dalam perkembangan self-esteem remaja.

Saran praktis, dalam pelaksanaan intervensi psikoedukasi self-esteem untuk penelitian selanjutnya sebaiknya melibatkan beberapa pihak terkait yang dinilai dapat mendukung keberhasilan intervensi yang akan dilaksanakan. Sebelum dimulainya intervensi sebaiknya peneliti bekerja sama dengan pihak sekolah untuk memberikan surat pemberitahuan kepada orangtua partisipan dalam rangka memberikan informasi yang berkaitan dengan intervensi psikoedukasi self-esteem yang akan diberikan kepada partisipan. Hal ini bertujuan agar orangtua dapat memberikan dukungan kepada partisipan sehingga diharapkan keberhasilan psikoedukasi self-esteem lebih optimal. Di sisi lain, waktu dan tempat intervensi psikoedukasi dapat memengaruhi tingkat keberhasilan intervensi yang dilaksanakan. Oleh karena itu, dalam pelaksanaan intervensi psikoedukasi selanjutnya sebaiknya peneliti memastikan waktu pelaksanaan intervensi yang tepat sehingga tidak mengganggu konsentrasi dan motivasi partisipan dalam mengikuti intervensi. Selain itu, tempat pelaksanaan juga perlu dipastikan bahwa tempat yang digunakan kondusif dan sesuai dengan setting penelitian. Pada penelitian selanjutnya, disarankan agar peneliti juga dapat memberikan training of trainer (ToT) kepada agen perubahan (agent of change) di sekolah yang bersangkutan, sehingga program psikoedukasi self-esteem yang diberikan diharapkan dapat terus berlanjut secara konsisten di sekolah tersebut dan dampak dari program yang diberikan dapat menjangkau lebih banyak siswa yang membutuhkan.

\section{Ucapan Terima Kasih (Acknowledgement)}


Peneliti mengucapkan terima kasih kepada segenap guru dan partisipan SMP X yang telah terlibat dalam penelitian ini. Terima kasih kepada SMP X yang telah memberikan kesempatan, kepercayaan dan dukungan penuh kepada peneliti untuk melaksanakan intervensi psikoedukasi di SMP X

\section{REFERENSI}

Ablog, J. A., \& Calaustro Jr, E. I. M. (2016). Effect of psychoeducation on self-esteem and selfefficacy among college students. Philippine Journal of Nursing, 87, 1.

Augestad, L. B. (2017). Self-concept and self-esteem among children and young adults with visual impairment: A systematic review. Cogent Psychology, 4, 1-12.

Bos, A. E. R., Muris, P., Mulkens, S., \& Schaalma, H. P. (2006). Changing self-esteem in children and adolescents: A roadmap for future interventions. Netherlands Journal of Psychology, 62, 26-33.

Brinthaupt, T. M., \& Lipka, R. P. (2002). Understanding early adolescent self and identity: Applications and interventions. New York, Albany: State University of New York.

Chemers M M., Hu L., \& Garcia B F. (2001). Academic self-efficacy and first-year college student performance and adjustment. Journal of Educational Psychology, 93, 55-64.

Franken, R. E. (2002). Human motivation (5th edition). USA: Wadsworth.

Guindon, M. H. (2010). Self-esteem across the lifespan. New York, NY: Taylor and Francis Group, LLC.

Gray-Little, B., Williams, V. S. L., \& Hancock, T. D. (1997). An item response theory analysis of the Rosenberg Self-Esteem Scale. Personality and Social Psychology Bulletin, 23, 443 451.

Hatcher, J., \& Hall, L. A. (2009). Psychometric properties of the Rosenberg Self-Esteem Scale in African American single mothers. Issues in Mental Health Nursing, 30, 70-77.

Helene, B., Bouchet, V., Bois, D., \& Lieutaud, A. (2017). The impacts of somatic psychoeducation on self-esteem. Ec Psychology and Psychiatry, 5, 43-51.

Lian, T. C,. \& Yusooff. F. (2009). The effects of family functioning on self-esteem of children. European Journal of Social Sciences, 643-650.

Lukens, E. P., \& McFarlane, W. R. (2004). Psychoeducation as evidence-based practice: Considerations for practice, research, and policy. Brief Treatment and Crisis Intervention, $4,3$.

Mruk, C. J. (2006). Self-esteem, research, theory, and practice: toward a positive psychology of self-esteem $3^{\text {rd }}$ edition. New York: Springer Publishing Company, Inc.

Orth, U., Robins, R. W., \& Trzesniewski, K.H. (2010). Self-esteem development from young adulthood to old age: A Cohort-Sequential Longitudinal Study. Journal of Personality and Social Psychology, 645-658.

Robins, R. W., \& Trzesniewski, K. H. (2005). Self-esteem development across the lifespan. American Psychological Society, 158-163.

Rosenberg, M. (1965). Society and the Adolescent Self-Image. United states, New Jersey: Princeton University Press.

Satir, Virginia., Banmen, J., Gerber, J., \& Maria, G. (2006). The satir model: Family therapy and beyond. Palo Alto, CA: Science and Behavior Books.

Schunk D H., \& Pajares F. (2012). Development of achievement motivation. San Diego: Academic Press

Schunk, Dale H., Zimmerman, \& Barry J. (2012). Motivation and self regulated learning: Theory, research, and application. New York: Lawrence Erlbaum Associated. 
Spencer, M. B., Dupree, D., \& Hartmann, T. (1997). A phenomenological variant of ecological systems theory (PVEST): A self-organization perspective in context. Development and Psychopathology, 9, 817-833.

Supriyatiknya, A. (2008). Merancang Program dan Modul Psikoedukasi. Yogyakarta: Universitas Sanata Dharma.

Wellbeing Service. (2015). Issues with self-esteem? Scotland, Glasgow: NHS. 